\title{
ASSESSMENT OF HEAVY METALS DISTRIBUTION IN THE SURFACE SEDIMENT OF KEMAMAN RIVER, TERENGGANU
}

\author{
VISHALINI B.MARAN ${ }^{1}$, DORINDA ANTHONY ANTHONY DASS ${ }^{1}$, LAVANNIA \\ RAVIKUMAR $^{1}$, NUR SYAMIMI IZYAN ZAINI ${ }^{1}$, NUR ALIAH SYAKIRAH ROSLI ${ }^{1}$, WAN \\ NUR IZWANI MIOR BAHARUDIN ${ }^{1}$, NAJAH KARIMAH MUSTAFFA ${ }^{1}$ AND ONG MENG \\ CHUAN ${ }^{1,2,3 *}$
}

\begin{abstract}
${ }^{1}$ Faculty of Science and Marine Environment, Universiti Malaysia Terengganu, 21030 Kuala Nerus, Terengganu ${ }^{2}$ Institute of Oceanography and Environment, Universiti Malaysia Terengganu, 21030 Kuala Nerus, Terengganu ${ }^{3}$ Ocean Pollution and Ecotoxicology (OPEC) Research Group, Universiti Malaysia Terengganu, 21030 Kuala Nerus, Terengganu
\end{abstract}

*Corresponding author: ong@umt.edu.my

http://doi.org/10.46754/umtjur.2021.07.003

\begin{abstract}
In the present day, rivers are used by people as water sources for their daily agricultural, industrial and cleaning purposes. However, industrial development and human activities are rapidly impacting the river's catchment area, which can cause contamination of heavy metals in the water and sediment. The Kemaman River is one of the rivers that may be affected by these pollutants. Thus, the concentration of selected heavy metals such as copper $(\mathrm{Cu})$, zinc $(\mathrm{Zn})$, cadmium $(\mathrm{Cd})$, lead $(\mathrm{Pb})$, arsenic $(\mathrm{As})$ and mercury $(\mathrm{Hg})$, plus the pollution status was determined in the surface sediments of the Kemaman River. A total of 46 sediment samples were collected along the river. Teflon Bomb digestion method with $2.0 \mathrm{~mL}$ of mixed acid (concentrated nitric acid, hydrochloric acid and hydrofluoric acid with ratio 3:3:1) was performed followed by analyzation using Inductively Coupled Plasma Mass Spectrometry (ICPMS). The status of heavy metals contamination in the study area was determined by the index of geoaccumulation $\left(\mathrm{I}_{\text {geo }}\right)$ and pollution load index (PLI). The calculated $\mathrm{I}_{\text {geo }}$ value suggested that the sediments in the Kemaman River were categorized under unpolluted to polluted category. However, the calculated PLI suggested that the study area is polluted with heavy metals. The correlation of the sediment mean grain size and the selected heavy metals was strongly correlated. The concentration of metals increased with the rising mean grain size, which suggests their association with the fine fraction of the sediment.
\end{abstract}

Keywords: heavy metals, sediment, Kemaman river, pollution, ICPMS

\section{Introduction}

The Kemaman River discharges freshwater of about $80 \mathrm{~m}^{3} / \mathrm{s}$ during the southwest monsoon season and $500 \mathrm{~m}^{3} / \mathrm{s}$ during the northeast monsoon season (Kamaruzzaman et al., 2002; Yusof, 2018). Industrial growth and human activities are increasingly impacting the river catchment area. A research carried out by Kamaruzzaman et al. (2002) found that the seawater intrusion into the Kemaman River is limited to a distance of $10 \mathrm{~km}$ upstream from the river mouth. Based on the collected data for 2020 obtained from the Malaysian Meteorological Department, the northeast monsoon season with strong winds and long frequency periods with a mean rainfall ranged from 141 to $614 \mathrm{~mm}$, was from November to January. On the other hand, the southwest monsoon season with low rainfall occurred from April to June (Kamaruzzaman et al., 2002).

Heavy metal is an element or metalloid with high atomic weight and its density is five times more than water. Heavy metals are hazardous due to their bioaccumulation and toxicity behaviour (Tchounwou et al., 2012). Another unique characteristic of these elements is that heavy metals cannot be degraded or destroyed (Ahmadipour et al., 2014). In the environment, heavy metal element concentration with less than $10 \mathrm{ppm}$, is considered as trace element due to its presence in trace concentration (KabataPendias, 2010). Heavy metals may settle down and accumulate in the marine sediment (Mansour et al., 2013; Ong et al., 2015). 
Pollution which occurs in the marine environment due to natural and anthropogenic activities by heavy metals is a worldwide problem (Zhu et al., 2013; Tang et al., 2014). Generally, the marine environment is suffering from human activities such as industrialization, agricultural and other activities. Due to anthropogenic activities such as fishing and industrial estate activities, heavy metal pollution might have affected the Kemaman River. However, some metals are essential in ecological function (Suresh et al., 2012), mainly to aquatic organisms. Since they are not removed from the water, metals can circulate in water bodies and settle down in the sediment bed or enter the food chain (Rai et al., 2015). Changes in metal disposal into the surrounding environment can affect the organisms and plants if the metals are higher than the ambient level due to their toxicity level.

This study aims to determine the distribution of heavy metal in surface sediment of the Kemaman and Chukai Rivers. Hence, the current pollution status on heavy metals in surface sediment of the Kemaman and Chukai Rivers is defined. The current finding may also provide a reference for future research.

\section{Materials and Methods}

Kemaman district is located at the latitude of $4^{\circ} 13^{\prime} 60^{\prime \prime} \mathrm{N}$ and longitude of $103^{\circ} 25^{\prime} 59^{\prime \prime} \mathrm{E}$, approximately $180 \mathrm{~km}$ southward of the Kuala Terengganu district. The Kemaman coastal area is a flat lowland and activities focus dominantly on fishing activities, local economic activities and farming. Two main rivers flow within this region, namely the Kemaman and Chukai Rivers. These two rivers are separated at the upstream and joined at the downstream, sharing the same estuary, known as the Kemaman River estuary. The Kemaman River has a greater discharge, mean annual discharge and is larger than the Chukai River.

Throughout this study, 33 sampling points were along the Kemaman River and 13 sampling points were along the Chukai River, with $500 \mathrm{~m}$ distance between each point. The surface sediment was collected using Ponar grab. The sampling activities were accomplished in October 2019. Figure 1 shows the sampling stations along the Kemaman and Chukai Rivers

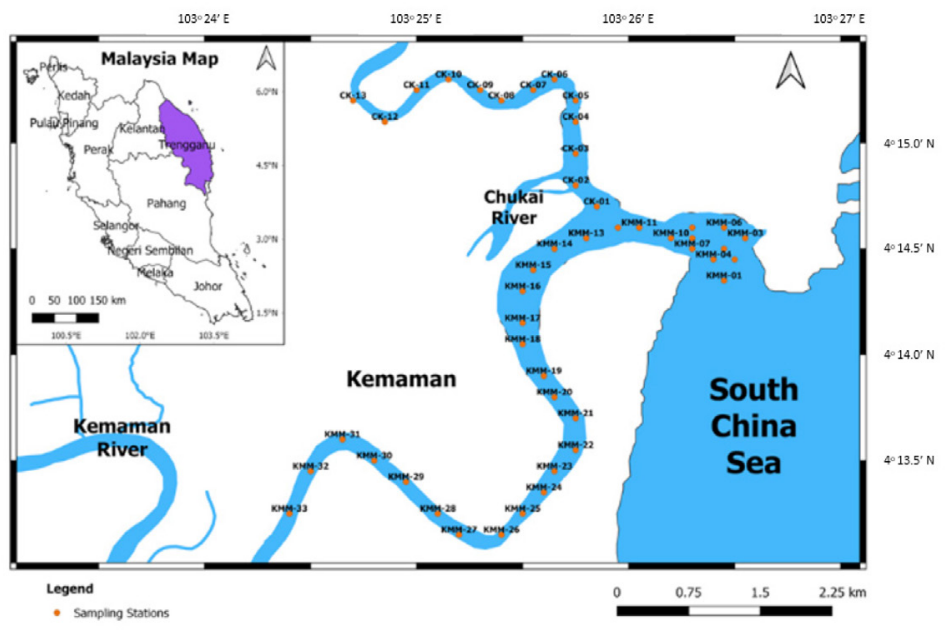

Figure 1: Map of sampling points in the Kemaman and Chukai Rivers

The collected sediments were digested using the method by Kamaruzzaman et al. (2010) and Ong et al. (2016) to obtain the heavy metal content. A total of $0.05 \mathrm{~g}$ of sieved sediment was weighed using an analytical balance and transferred to a Teflon beaker. Next, $2.0 \mathrm{~mL}$ of mixed concentrated acids, which are nitric acid $\left(\mathrm{HNO}_{3}\right)$, hydrochloric acid $(\mathrm{HCl})$ and hydrofluoric acid (HF) with a ratio of $3: 3: 1$, respectively, were added to the sediment and 
heated in the oven for 8 hours at $100{ }^{\circ} \mathrm{C}$. The digested samples were then cooled to room temperature, transferred into centrifuge tubes and milli-Q water was added up to $10 \mathrm{~mL}$. Samples were kept in the freezer until further analysis. The concentrations of heavy metals were determined using Inductively Coupled Plasma Mass Spectrometry (ICP-MS) (Ong et al., 2015) and recorded in the Microsoft Excel spreadsheet. The accuracy of the digestion method was checked against blank samples and Standard Reference Material, SRM 1646a Estuarine Sediment.

For the particle size analysis, two methods were used since the samples comprise of sandy and fine particle samples. For fine particle samples, a total of $2 \mathrm{~g}$ sample was diluted with distilled water and calgon solution was added in the samples to disperse bonded particles in the sediment by organic matter. After 24 hours, the sample was measured using the Particle Size Analyzer laser diffraction method (Joseph et al., 2020). For sandy particles, the samples were sieved using sieve shaker with 13 series sieving from the top to bottom of $4000 \mu \mathrm{m}, 2800 \mu \mathrm{m}$, $2000 \mu \mathrm{m}, 1400 \mu \mathrm{m}, 1000 \mu \mathrm{m}, 710 \mu \mathrm{m}, 500 \mu \mathrm{m}$,
$355 \mu \mathrm{m}, 180 \mu \mathrm{m}, 125 \mu \mathrm{m}, 90 \mu \mathrm{m}, 63 \mu \mathrm{m}$ and less than $63 \mu \mathrm{m}$. The sieve shaker was shaken for 15 minutes. The weight of the samples in each sieve was recorded (Joseph et al., 2020). Next, GRADISTAT software was used to calculate the mean size particle and determine the type of sediment classification.

\section{Results and Discussion}

Generally, the sediment mean size value gives a simple indication of the degree of the force by water or wind which transports the sediment grain (Durán et al., 2011). Grain size is vital to identify the sediment particles entrainment, transportation and deposition (Singovszka et al., 2016). In this study, surface sediments vary from very coarse sand to coarse silt at both the Kemaman and Chukai Rivers. Increasing in mean size value indicates a decrease in grain size and vice versa. Figure 2 shows the sediment mean size value at each sampling station. The higher mean size value in the study area was observed at KMM-33 (-0.47Æ) which indicates very coarse sand due to the high energy in the environment (Sallenger and Richmond, 2011). The lowest mean size was found at KMM-28 $(5.87 Æ)$ with indicates coarse silt.

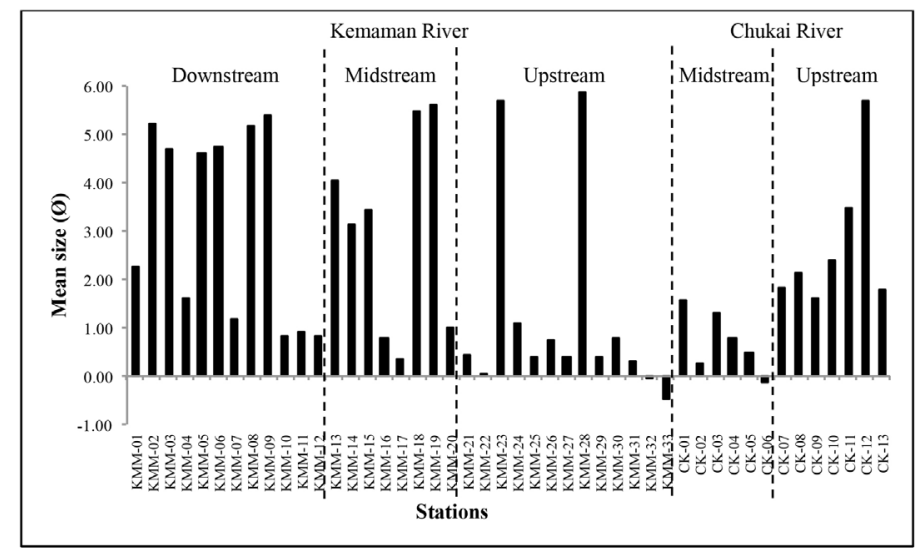

Figure 2: Mean grain size across all stations at the Kemaman and Chukai Rivers

Stronger water current in a particular study area makes the sediment coarse. This is due to the high velocity of the river water flows which transports the fine sand, and leaves the coarser sand on the river bed. Additionally, a high amount of suspended sediment is transported to the estuary and settled down during tidal (Kamaruzzaman et al., 2002). 
Table 1 shows the average concentration of heavy metals in the Kemaman and Chukai Rivers sediment and Figure 3 shows the distribution of metals in the sediment of the Kemaman and Chukai Rivers. The concentration of $\mathrm{Cu}$ shows high level at the downstream zone compared to upstream zone (Figure 3). The mean value recorded for the concentration of $\mathrm{Cu}$ was $15.1 \pm 11.8 \mu \mathrm{g} / \mathrm{g}$ dry weight. The lowest concentration of $\mathrm{Cu}$ was recorded at KMM11 with $2.40 \mu \mathrm{g} / \mathrm{g}$ dry weight whereas high concentration of $\mathrm{Cu}$ was found at KMM-03, with $45.6 \mu \mathrm{g} / \mathrm{g}$ dry weight. Meanwhile, the average value for $\mathrm{Zn}$ was $60.2 \pm 59.4 \mu \mathrm{g} / \mathrm{g}$ dry weight. The concentration of $\mathrm{Zn}$ was in the range of 1.77 to $210 \mu \mathrm{g} / \mathrm{g}$ dry weight. Similar to $\mathrm{Cu}$, the concentration of $\mathrm{Zn}$ was high at the downstream zone compared to upstream zone. The lowest concentration of $\mathrm{Zn}$ was recorded at the CK-09 and highest concentration at KMM-13.

The concentration of $\mathrm{Cd}$ was also high at the downstream zone compared to the upstream zone. In this study, the mean value for the concentration of $\mathrm{Cd}$ was $0.10 \pm 0.07 \mu \mathrm{g} / \mathrm{g}$ dry weight. The lowest concentration of $\mathrm{Cd}$ was recorded at the KMM-26 with $0.01 \mu \mathrm{g} / \mathrm{g}$ dry weight, while KMM- 08 recorded the highest concentration of $\mathrm{Cd}$, with $0.27 \mu \mathrm{g} / \mathrm{g}$ dry weight.
The concentration of $\mathrm{Pb}$ varied between the sampling stations. The highest and lowest concentrations of $\mathrm{Pb}$ were $2.71 \mu \mathrm{g} / \mathrm{g}$ dry weight at CK-13 and $65.8 \mu \mathrm{g} / \mathrm{g}$ dry weight at KMM-08, respectively. Figure 3 shows the concentration of $\mathrm{Pb}$ in the surface sediment samples of the Kemaman and Chukai River. The concentration of $\mathrm{Pb}$ was high at downstream compared to upstream. In this study, the average value for concentration of $\mathrm{Pb}$ was $24.4 \pm 19.5 \mu \mathrm{g} / \mathrm{g}$ dry weight.

The mean value for the concentration of As in the Kemaman and Chukai River sediment was $3.78 \pm 3.15 \mu \mathrm{g} / \mathrm{g}$ dry weight. The highest concentration of As was recorded at KMM-03 and the lowest at CK-13. The values ranged from 0.64 to $14.2 \mu \mathrm{g} / \mathrm{g}$ dry weight. The concentration of As showed a high concentration at the downstream zone compared to the upstream zone. On the other hand, the concentration of total mercury (T-Hg) was high at the downstream zone compared to the upstream zone. The mean value for the concentration of $\mathrm{T}-\mathrm{Hg}$ was $0.01 \pm 0.05 \mu \mathrm{g} / \mathrm{g}$ dry weight. The lowest concentration of $\mathrm{T}-\mathrm{Hg}$ was recorded at the KMM-32 with $0.01 \mu \mathrm{g} / \mathrm{g}$ dry weight whereas KMM-13 recorded the highest concentration of T-Hg with $0.15 \mu \mathrm{g} / \mathrm{g}$ dry weight.

Table 1: The average concentration of heavy metals in the surface sediment samples of the Kemaman and Chukai Rivers, Terengganu

\begin{tabular}{ccccccc}
\hline & \multicolumn{7}{c}{ Average Concentration $(\boldsymbol{\mu g} / \mathbf{k g}$ dry weight $)$} \\
\cline { 2 - 7 } Zones & $\mathbf{C u}$ & $\mathbf{Z n}$ & $\mathbf{C d}$ & $\mathbf{P b}$ & $\mathbf{A s}$ & $\mathbf{T}-\mathbf{H g}$ \\
\hline Downstream & 19.6 & 87.4 & 0.14 & 35.6 & 6.04 & 0.08 \\
Midstream & 18.3 & 71.1 & 0.10 & 26.1 & 3.84 & 0.06 \\
Upstream & 10.1 & 36.3 & 0.07 & 16.4 & 2.39 & 0.03 \\
\hline
\end{tabular}




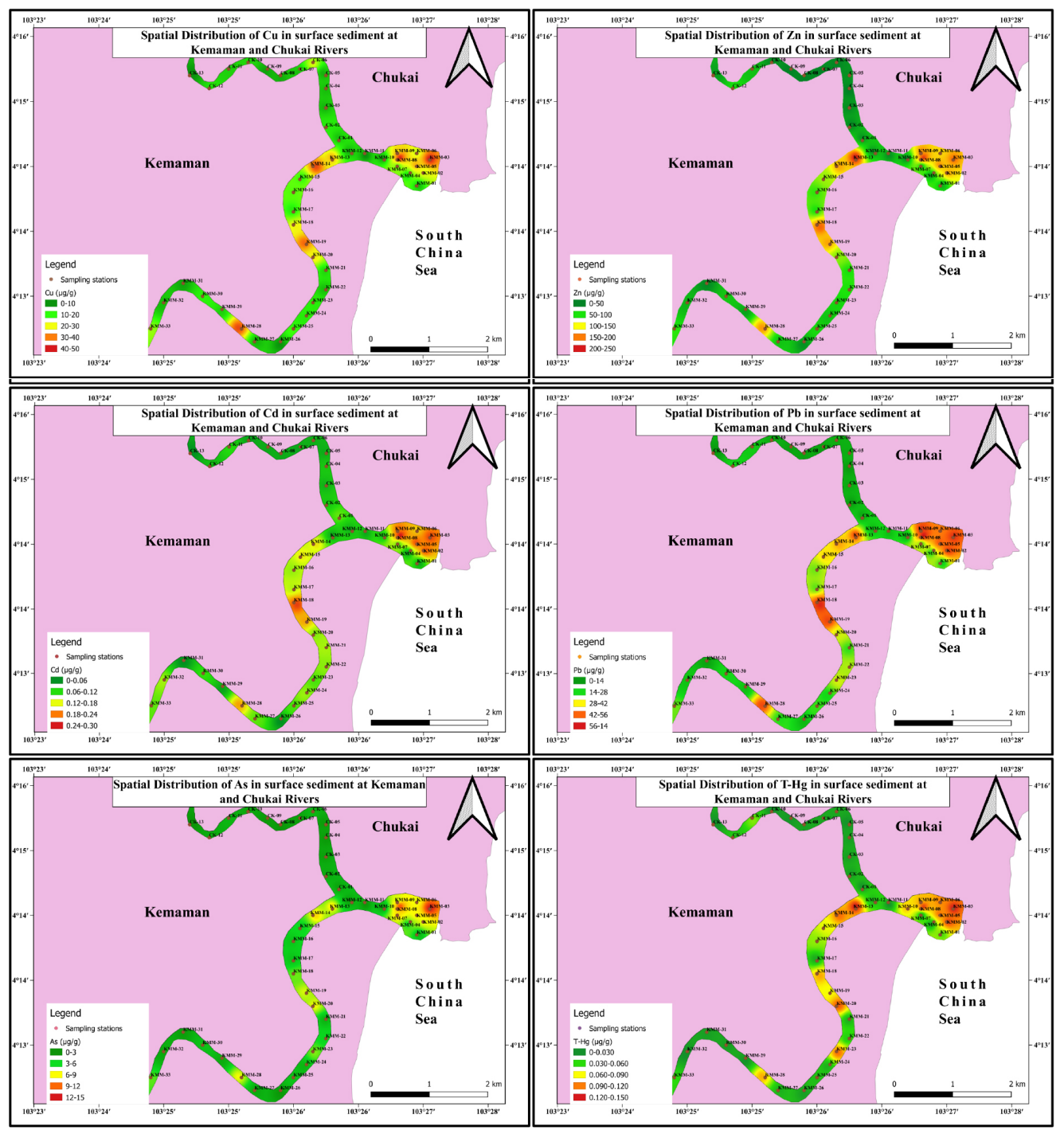

Figure 3: The distribution of metal concentration in the surface sediments of the Kemaman and Chukai Rivers, Terengganu using ArcGIS software

The grain size distribution of the sediments play a vital role in controlling the concentration and distribution of studied heavy metals (Sany et al., 2013). This is due to the mobility of heavy metals in the sediments and water was controlled by several factors such as erosion, sedimentation, sediment type, water dynamics, urbanization, industrialization, river discharge and geochemical reactions (Liu et al., 2011;
Sany et al., 2013). Throughout this study, the heavy metal concentration in the Kemaman and Chukai Rivers increased with a decrease in sediment size. Figure 4 shows the correlation value between heavy metals and sediment size. Lead showed a high relationship with sediment mean size which is $\mathrm{r}=0.76$, followed by $\mathrm{Zn}$ $(\mathrm{r}=0.74)$ and $\mathrm{T}-\mathrm{Hg}(\mathrm{r}=0.72)$ which also indicates strong correlation. 


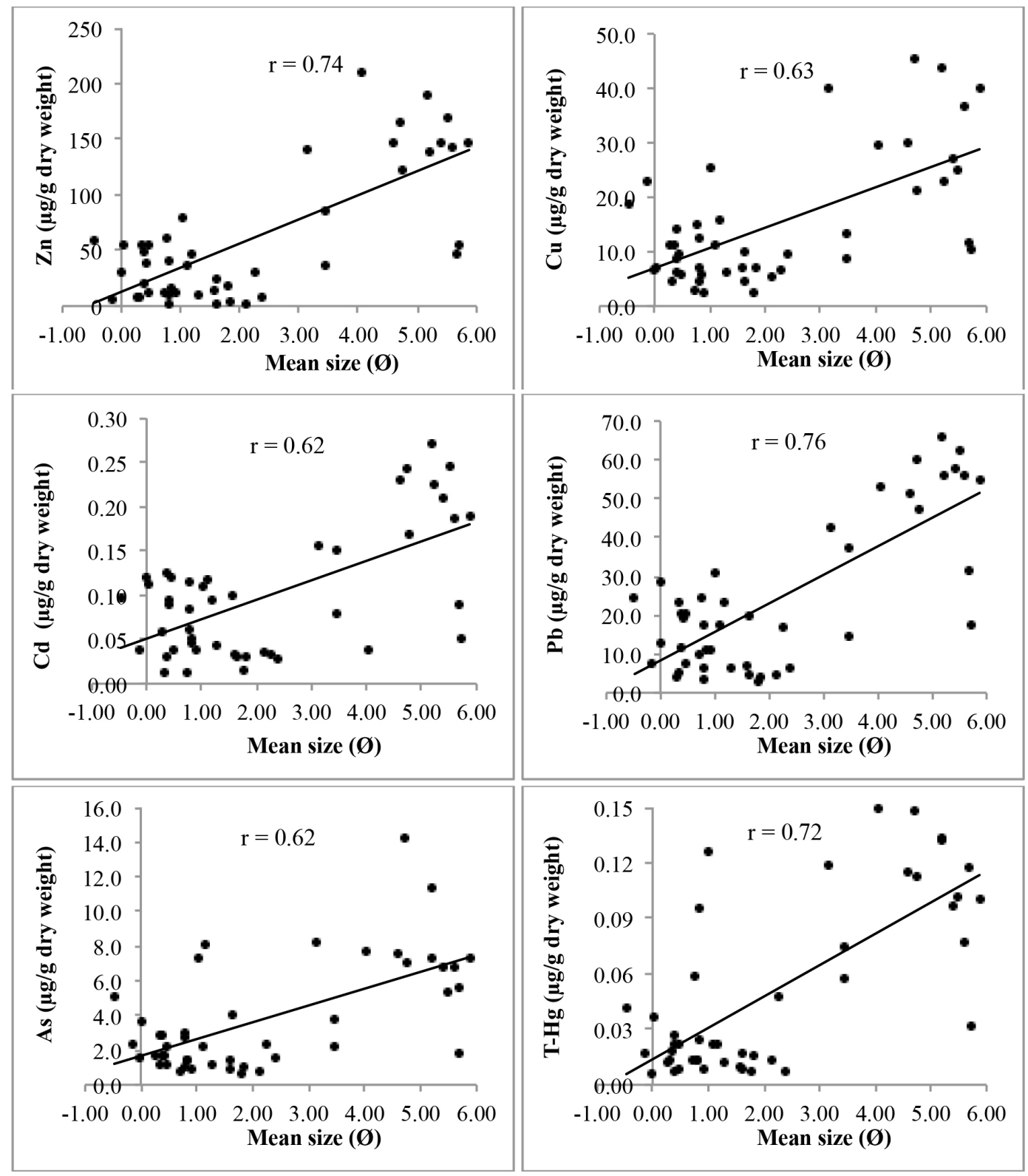

Figure 4: Correlation between sediment size and heavy metal in the Kemaman and Chukai Rivers 
The positive correlation coefficient between sediment size and heavy metals shows that the heavy metals are directly proportional to the particle size (Ong et al., 2015). Coarse sediment size has a smaller ratio of surface area whereas fine sediment size has a larger surface area (Amin et al., 2008; Ong et al., 2013). Coarser sediments might contain a high composition of quartz and feldspar which lead to a lesser accumulation of heavy metals (Liu et al., 2011). The fine sediment size gives a larger area of a binding site for heavy metals ion from the bottom layer of the water column (Yuan et al., 2011; Bainbridge et al., 2012).

Besides that, the correlation matrix explains that all the heavy metals have a good degree of relationship between each other. The positive correlations coefficient value was illustrated in Table 2. The strong correlation between
$\mathrm{Pb}$ and $\mathrm{Zn}(\mathrm{r}=0.97)$ might be due to the city sewage effluents that accumulate $\mathrm{Zn}$ and $\mathrm{Pb}$ in sediment (Chakarvorty et al., 2015). The strong relationship between $\mathrm{As}$ and $\mathrm{Cu}(\mathrm{r}=0.90)$ demonstrates a significant degree of positive correlation and might be influenced by similar possible sources (Singh et al., 2017). The significant relationship between $\mathrm{T}-\mathrm{Hg}$ and $\mathrm{Cd}$ $(\mathrm{r}=0.70)$, As and $\mathrm{Cd}(\mathrm{r}=0.77)$ were observed for their existence in the sediment samples and might be the characteristics of the natural origin for the heavy metals in the river sediment (Abdullah et al, 2015; Singh et al., 2017). Therefore, it is suggested that these metals may come from the same source, mutual dependence and have similar behavior in transportation which is similar to those found by Suresh et al. (2012), Bastami et al. (2014), Dou et al. (2013) and Singh et al. (2017).

Table 2: The correlation coefficient between heavy metals in the Kemaman and Chukai Rivers surface sediment

\begin{tabular}{lccccc}
\hline & $\mathrm{Cu}$ & $\mathrm{Zn}$ & $\mathrm{Cd}$ & $\mathrm{Pb}$ & $\mathrm{As}$ \\
\hline $\mathrm{Zn}$ & 0.88 & & & & \\
$\mathrm{Cd}$ & 0.78 & 0.82 & & & \\
$\mathrm{~Pb}$ & 0.86 & 0.97 & 0.88 & & \\
$\mathrm{As}$ & 0.90 & 0.86 & 0.77 & 0.88 & \\
$\mathrm{~T}-\mathrm{Hg}$ & 0.79 & 0.86 & 0.70 & 0.86 & 0.84 \\
\hline
\end{tabular}

Index of geoaccumulation ( $\left.\mathrm{I}_{\text {geo }}\right)$ was initially proposed by Muller (1969) to determine and define the metal contamination in sediment. Igeo is used to assess the contamination level of selected heavy metals in sediments by comparing with the background value or baseline (Muller, 1979; Mei et al., 2011); plus, the results reflect the effect of lithogenic sources (Nobi et al. 2010; Sany et al., 2013). The following equation is commonly used to calculate the metal contamination:
Where $\mathrm{Cn}$ is the measured concentration of elements " $n$ " in the sediment. $\mathrm{Bn}$ is the background value for the metal " $n$ " (Wedepohl, 1995). Factor 1.5 indicates the possible variations of the background values due to lithogenic effects (Muller, 1969). Table 3 shows the classification of Igeo.

$$
\text { Igeo }=\log _{2}\left(\frac{\mathrm{Cn}}{1.5 \mathrm{Bn}}\right)
$$


Table 3: Classification of $I_{\text {geo }}$ (Muller, 1969)

\begin{tabular}{ccc}
\hline Igeo class & Igeo & Description of sediment quality \\
\hline $\mathbf{0}$ & $<0$ & Unpolluted \\
$\mathbf{1}$ & $0-1$ & Unpolluted to moderately contaminated \\
$\mathbf{2}$ & $1-2$ & Moderately polluted \\
$\mathbf{3}$ & $2-3$ & Moderately to strongly polluted \\
$\mathbf{4}$ & $3-4$ & Strongly polluted \\
$\mathbf{5}$ & $4-5$ & Strongly to extremely polluted \\
\hline
\end{tabular}

Based on the Igeo value, the trend of heavy metal pollution in the surface sediment of the Kemaman and Chukai Rivers are in the decreasing as follow, $\mathrm{As}>\mathrm{Pb}>\mathrm{Cu}>\mathrm{Cd}>\mathrm{Zn}$
$>$ T-Hg (Table 4). Cd and T-Hg are classified as unpolluted to moderately contaminated, while $\mathrm{Cu}, \mathrm{Pb}$ and $\mathrm{Zn}$ are categorized as unpolluted to moderately polluted. Only As is found to be unpolluted to strongly polluted.

Figure 4: Pollution level of heavy metals based on Igeo classification (Muller, 1969) in the Kemaman and Chukai Rivers sediment

\begin{tabular}{cccc}
\hline Metals & Mean & Min-Max & Category \\
\hline $\mathrm{Cd}$ & -1.05 & $-3.73-0.83$ & Unpolluted to moderately contaminated \\
$\mathrm{T}-\mathrm{Hg}$ & -1.43 & $-3.87-0.83$ & \\
$\mathrm{Cu}$ & -0.93 & $-3.16-1.09$ & \\
$\mathrm{~Pb}$ & -0.59 & $-3.23-1.36$ & Unpolluted to moderately polluted \\
$\mathrm{Zn}$ & -1.28 & $-5.46-1.43$ & \\
\hline $\mathrm{As}$ & -0.14 & $-2.23-2.25$ & Unpolluted to strongly polluted \\
\hline
\end{tabular}

The Pollution Load Index (PLI) gives a better understanding on the level of heavy metal contamination in the surface sediments (Tomlinson et al., 1980; Barakat et al., 2012). The PLI value is calculated using the following formula:

$$
\mathrm{PLI}=\left(\mathrm{CF}_{1} \times \mathrm{CF}_{2} \times \mathrm{CF}_{3} \times \ldots . . \mathrm{CFn}\right)^{1 / n}
$$

Where $\mathrm{CF}$ is the contamination factor for each metal. The contamination factor (CF) is the concentration of heavy metal in sediment which is divided by the background values (Rabee et al., 2011). " $\mathrm{n}$ " is the number of metal of the studied metals. The PLI can be classified as polluted if the value is larger than 1 whereas PLI value less than 1 shows that no pollution occurs in the study area.

Figure 5 illustrates the PLI value of the studied heavy metals for each station. The range of PLI value was 0.20-3.42 and the average value was 1.14. This indicates that the Kemaman and Chukai River sediment are slightly polluted by the studied metals. The PLI values with less than 1 were mostly found in the upstream zone. Besides that, the PLI values with more than 1 were found at the downstream and midstream areas. 


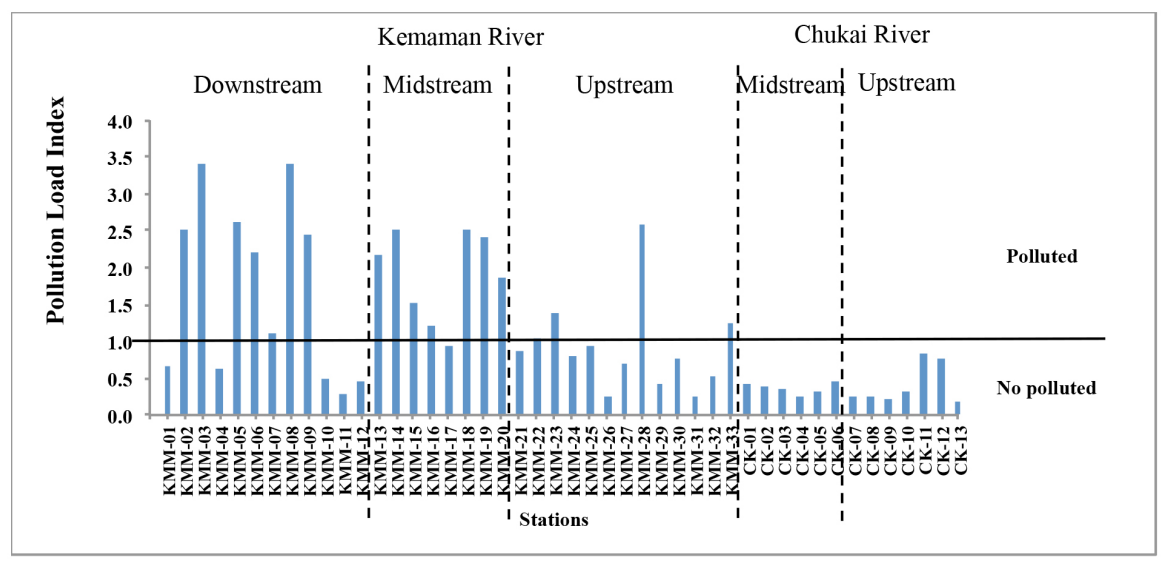

Figure 5: PLI value for studied heavy metals for each station at the Kemaman and Chukai Rivers

Based on PLI analysis, the downstream and midstream zones tend to have high occurrence of contamination compared to the upstream zone. This is due to the high intense of human activities found at the downstream and midstream zones (Ong et al., 2012). Station KMM-03 showed the highest value of PLI due to the highest concentration in $\mathrm{Cu}$ and As among the sampling stations. Additionally, this station was also located within high fishing activity area. This is due to some sources of heavy metals which may have resulted by from the boat activities. Water can also transport high concentration of suspended sediments which contain metals due to the strong water current to the estuary areas (Kamaruzzaman et al., 2002).

Low contamination of metals occurred in the upstream zone. Higher hydrodynamic energy provides lesser resident time for metals to be absorbed in surface sediments (Sany et al., 2013). Thus, high portion of coarser grain size sediments was determined (Zhou et al., 2014). Metal ions are not easily absorbed by the water molecules, therefore, least of dissolved metals will be transported to the downstream zone (Sany et al., 2013). Thus, highest heavy metal contamination was obtained in surface sediments at downstream.

\section{Conclusion}

The sedimentological characteristics for the Kemaman and Chukai Rivers were categorized as fine sand according to the mean size classification. The mean concentration of heavy metals was recorded as $\mathrm{Zn}(60.2 \pm 59.4 \mu \mathrm{g} / \mathrm{g}$ dry weight $)>\mathrm{Pb}(24.4 \pm 19.5 \mu \mathrm{g} / \mathrm{g}$ dry weight $)$ $>\mathrm{Cu}(15.1 \pm 11.84 \mu \mathrm{g} / \mathrm{g}$ dry weight $)>\mathrm{As}$ $(3.78 \pm 3.15 \mu \mathrm{g} / \mathrm{g}$ dry weight $)>\mathrm{Cd}(0.10 \pm 0.07$ $\mu \mathrm{g} / \mathrm{g}$ dry weight $)>\mathrm{T}-\mathrm{Hg}(0.01 \pm 0.047 \mu \mathrm{g} / \mathrm{g}$ dry weight). Generally, the downstream zone of the Kemaman and Chukai Rivers tends to have high concentration of heavy metals. Additionally, there is high relationship among each other in surface sediment from the Kemaman and Chukai Rivers. In conclusion, all metals were derived from the same source, plus all heavy metals are positively correlated with the sediment particles. The mean grain size might be important in controlling factors affecting the concentration and transportation of heavy metals. Coarse sediments has low ratio of surface area for metal ion absorption compared to fine sediments. According to average Igeo classification for individual metals, the contamination levels of heavy metals are not polluted. Some sampling stations were polluted with the studied metals. In contrast, based on the PLI value calculated, surface sediment of the Kemaman and Chukai Rivers can be classified as slightly polluted by metals. Therefore, continuous monitoring and further studies are recommended at the study area to determine the long term effects of metals on the riverine environment. This is to ensure no elevated pollution occurs which could affect the riverine ecosystem and the human pollution depending on the rivers. 


\section{Acknowledgement}

Authors wished to thank the university for the research opportunity and the reviewers for the constructive comments towards this article.

\section{References}

Abdullah, M. Z., Abd Manap, N. R., Saat, A., Hamzah, Z., \& Abas, M. T. (2015). Evaluation of heavy metal contamination levels of Balok River sediments in Pahang, Malaysia based on geoaccumulation index and supported with enrichment factor. Malaysian Journal of Analytical Sciences, 19(4), 707-714.

Ahmadipour, F. Bahramifar, N. and Ghasempouri, S.M. (2014) Fractionation and mobility of cadmium and lead in soils of Amol area in Iran, using the modified BCR sequential extraction method. Chemical. Speciation. Bioavailable, 26(1), 31-36

Amin, B., Ismail, A., Arshad, A., Yap, C. K., \& Kamarudin, M. S. (2008). Anthropogenic impacts onheavy metal concentrations in the coastal sediments of Dumai, Indonesia. Environmental Monitoring and Assessment, 148(1-4), 291-305.

Bainbridge, Z. T., Wolanski, E., ÁlvarezRomero, J. G., Lewis, S. E., \& Brodie, J. E. (2012). Fine sediment and nutrient dynamics related to particle size and floc formation in a Burdekin River flo

od plume, Australia. Marine Pollution Bulletin, 65(4-9), 236-248.

Barakat, A., El Baghdadi, M., Rais, J., \& Nadem, S. (2012). Assessment of heavy metal in surface sediments of Day River at BeniMellal region, Morocco. Research Journal of Environmental and Earth Sciences, 4(8), 797-806.

Bastami, K. D., Bagheri, H., Kheirabadi, V., Zaferani, G. G., Teymori, M. B., Hamzehpoor, A., \& Ganji, S. (2014). Distribution and ecological risk assessment of heavy metals in surface sediments along southeast coast of the Caspian Sea. Marine Pollution Bulletin, 81(1), 262- 267.

Chakarvorty, M., Dwivedi, A. K., Shukla, A. D., Kumar, S., Niyogi, A., Usmani, M. \& Pati, J. K. (2015). Geochemistry and magnetic measurements of suspended sediment in urban sewage water vis-à-vis quantification of heavy metal pollution in Ganga and Yamuna Rivers, India. Environmental Monitoring and Assessment, 187, 604.

Dou, Y., Li, J., Zhao, J., Hu, B., \& Yang, S. (2013). Distribution, enrichment and source of heavy metals in surface sediments of the eastern Beibu Bay, South China Sea. Marine Pollution Bulletin, 67(1-2), 137-145.

Durán, O., Claudin, P., \& Andreotti, B. (2011). On aeolian transport: Grain-scale interactions, dynamical mechanisms and scaling laws. Aeolian Research, 3(3), 243270 .

Joseph, B., Adiana, G., Ong, M.C., Shazili, N.A.M., Shaari, H. (2020). Scrutinizing the anthropogenic metals in the Brunei Bay sediment cores off the Malaysian waters. Environmental Earth Sciences, 79(19), 452.

Kabata-Pendias, A. (2010). Trace elements in soils and plants. CRC press.

Kamaruzzaman, B. Y., Shazili, N. A. M., \& Mohd Lokman, H. (2002). Particle size distribution in the bottom sediments of the Kemaman River estuarine system, Terengganu, Malaysia. Pertanika Journal of Tropical Agricultural Science, 25(2), 149-156.

Kamaruzzaman, Y., Siti Waznah, A., Ong. M. C., \& Joseph, B. (2010). Spatial Distribution of Lead and Copper in the Bottom Sediments of Pahang River Estuary, Pahang, Malaysia. Sains Malaysiana, 39(4), 543-547.

Liu, S., Shi, X., Liu, Y., Zhu, Z., Yang, G., Zhu, A., \& Gao, J. (2011). Concentration distribution and assessment of heavy metals in sediments of mud area from inner continental shelf of the East China Sea. Environmental Earth Sciences, 64(2), 567579. 
Mansour, A. M., Askalany, M. S., Madkour, H. A., Assran, B. B. (2013). Assessment and comparison of heavy-metal concentrations in marine sediments in view of tourism activities in Hurghada area, northern Red Sea, Egypt. The Egyptian Journal of Aquatic Research, 39(2) ,1-103.

Mei, J., Li, Z., Sun, L., Gui, H., \& Wang, X. (2011). Assessment of heavy metals in the urban river sediments in Suzhou City, northern Anhui Province, China. Procedia Environmental Sciences, 10, 2547-2553.

Muller, G., 1969. Index of geoaccumulation in sediments of the Rhine River, Geojournal, $2,108-118$.

Muller, G., 1979. Schwermetalle in den sediments des Rheins-Veran-derungen seitt 1971. Umschan 79, 778-783.

Nobi, E., Dilipan, E., Thangaradjou, T., Sivakumar, K., \& Kannan, L. (2010). Geochemical and geo-statistical assessment of heavy metal concentration in the sediments of different coastal ecosystems of Andaman Islands, India. Estuarine, Coastal and Shelf Science, 87(2), 253-264.

Ong, M. C., Joseph, B., Shazili, N. A. M., Ghazali, A., \& Mohamad, M.N. (2015). Heavy metals concentration in surficial sediments of Bidong Island, South China Sea off the East Coast of Peninsular Malaysia. Asian Journal of Earth Sciences, 8(3), 74-82.

Ong, M. C., Kamaruzzaman, B. Y., \& Azhar, M. N. (2012). Sediment characteristic studies in the surface sediment from Kemaman Mangrove Forest, Terengganu, Malaysia. Oriental Journal of Chemistry, 28(4), 1639.

Ong, M. C., Fok, F. M., Sultan, K. \& Joseph, B. (2016). Distribution of Heavy Metals and Rare Earth Elements in the Surface Sediments of Penang River Estuary, Malaysia. Open Journal of Marine Science, 6(1), 62982.
Ong. M. C., Joseph, B., Shazili, N. A. M., Ghazali, A. \& Mohamad, M. N. (2015). Heavy metals concentration in surficial sediments of Bidong Island, South China Sea off the East coast of peninsular Malaysia. Asian Journal of Earth Sciences, 8(3), 74.

Rabee, A. M., Al-Fatlawy, Y. F., \& Nameer, M. (2011). Using Pollution Load Index (PLI) and geoaccumulation index (IGeo) for the assessment of heavy metals pollution in Tigris river sediment in Baghdad Region. Al-Nahrain Journal of Science, 14(4), 108114.

Rai, S., Gupta, S., \& Mittal, P. C. (2015). Dietary intakes and health risk of toxic and essential heavy metals through the food chain in agricultural, industrial, and coal mining areas of northern India. Human and Ecological Risk Assessment: An International Journal, 21(4), 913-933.

Sany, S. B. T., Salleh, A., Rezayi, M., Saadati, N., Narimany, L., \& Tehrani, G. M. (2013). Distribution and contamination of heavy metal in the coastal sediments of Port Klang, Selangor, Malaysia. Water, Air, \& Soil Pollution, 224(4), 1476.

Singh, H., Pandey, R., Singh, S. K., \& Shukla, D. N. (2017). Assessment of heavy metal contamination in the sediment of the River Ghaghara, a major tributary of the River Ganga in Northern India. Applied Water Science, 7(7), 4133-4149. doi:10.1007/ s13201-017-0572-y

Singovszka, E., Junakova, N., \& Balintova, M. (2016). The effect of sediment grain size on heavy metal content in different depth in water reservoir Ruzin, Slovakia. In Solid State Phenomena (Vol. 244, pp. 240-245). Trans Tech Publications Ltd.

Suresh, G., Sutharsan, P., Ramasamy, V., \& Venkatachalapathy, R. (2012). Assessment of spatial distribution and potential ecological risk of the heavy metals in relation to granulometric contents of Veeranam lake sediments, India. Ecotoxicology and Environmental Safety, 84, 117-124. 
Tang, W., Shan, B., Zhang, H., Zhang, W., Zhao, Yuan, H. Z., Shen, J., Liu, E. F., Wang, J. J., \& Y., Ding, Y., Rong, N., Zhu, X. (2014). Heavy metal contamination in the Surface Sediments of Representative Limnetic Ecosystems in Eastern China. Scientific Reports, 4, 7152. Meng, X. H. (2011). Assessment of nutrients and heavy metals enrichment in surface sediments from Taihu Lake, a eutrophic shallow lake in China. Environmental Geochemistry and Health, 33(1), 67-81.

Tchounwou, P. B., Yedjou, C. G., Patlolla, A. K., \& Sutton, D. J. (2012). Heavy metal toxicity and the environment. Experientia supplementum, 101, 133-64.

Tomlinson, D.L., Wilson, C.R., Harris, C.R., Jeffrey, D.W. (1980) Problems in the assessment of heavy-metal levels in the estuaries and the formation of a pollution index. Hergoland Marine Research, 33(14), 566-575.

Wedepohl, K. H. (1995). The composition of the continental crust. Geochimica et cosmochimica Acta, 59(7), 1217-1232.

Yusof, F. M. (2018). Habitat Predictive Modelling and Geospatial Database of Batagur Affinis (Contor, 1847) in Kemaman River, Malaysia. Master of Science Thesis, Universiti Putra Malaysia, 112p.

Zhou, G., Sun, B., Zeng, D., Wei, H., Liu, Z., \& Zhang, B. (2014). Vertical distribution of trace elements in the sediment cores from major rivers in east China and its implication on geochemical background and anthropogenic effects. Journal of Geochemical Exploration, 139, 53-67.

Zhu, X., Ji, H., Chen, Y., Qiao, M., \& Tang, L. (2013). Assessment and sources of heavy metals in surface sediments of Miyun Reservoir, Beijing. Environmental monitoring and assessment, 185(7), 60496062. 